\title{
Implementasi Penguatan Pendidikan karakter melalui budaya sekolah di SD negeri 26 Dompu dan MI As -Salam Dompu
}

\author{
Junari Yulianti, Ichsan \\ Universitas Islam Negeri sunan kalijaga Yogyakarta, Universitas Islam Negeri Sunan \\ Kalijaga Yogyakarta \\ e-mail: anainabau45@gmail.com, Ichsan@gmail.com
}

\begin{abstract}
Based on the results of research conducted in two schools, namely SD Negeri 30 Dompu and MI AS-Salam Dompu related to "Implementation of Character Education Values Through School Culture at SD Negeri 26 Dompu and MI As - Salam Dompu". The aim of this research is to describe character education plans through school culture at SD Negeri 26 Dompu and MI As - Salam Dompu. Research methodology The research used a descriptive qualitative approach. This type of research is a multi-case study (multicase studies) is a study that seeks to take in-depth and detailed data from sources. Interview data collection techniques, observation and documentation. Problems that occur in the field, this research focuses on three main character values, namely religious, nationalist and independent. The three character values were chosen because these character values are still not visible in the ongoing educational process. For the explanation above, it is very important to implement character education in schools as an effort to make students aware of the importance of complying with applicable rules and having a commitment to continue implementing good values in their lives.
\end{abstract}

Keywords: Implementation, Character Education, School Culture

\begin{abstract}
ABSTRAK
Berdasarkan hasil penelitian yang dilakukan di dua sekolah yaitu SD Negeri 30 Dompu dan MI AS- Salam Dompu yang terkait "Implementasi Nilai-Nilai Pendidikan Karakter Melalui Budaya Sekolah di SD Negeri 26 Dompu Dan MI As - Salam Dompu". mendapatkan tujuan penelitiannya adalah Mendeskripsikan percenanaan pendidikan karakter melalui budaya sekolah di SD Negeri 26 Dompu dan MI As - Salam Dompu. Metodelogi penelitian Penelitian menggunakan pendekatan kualitatif deskriptif. Jenis penelitian studi multi kasus (multycase studies) merupakan studi yang berusaha untuk mengambil data yang mendalam dan terperinci dari narasumber. Teknik pengumpulan data wawancara , observasi dan Dokumentasi. Permasalahan yang terjadi di lapangan, penelitian ini memfokuskan pada tiga nilai karakter utama yaitu religius, nasionalis dan mandiri. Ketiga nilai karakter tersebut dipilih karena nilai karakter tersebut masih kurang nampak pada proses pendidikan yang berlangsung. Untuk pemaparan di atas sangat penting implementasi pendidikan karakter diterapkan di sekolah-sekolah sebagai upaya untuk menyadarkan peserta didik akan pentingnya mematuhi aturan yang berlaku serta memiliki komitmen untuk terus melaksanakan nilai-nilai kebaikan dalam kehidupannya
\end{abstract}

Kata Kunci : Implementasi, Pendidikan Karakter,Budaya Sekolah 


\section{PENDAHULUAN}

Eksitensi dan aspek dalam suatu Bangsa ditinjau dari moral ataupun karakter yang dimilikinya ${ }^{1}$. Pendidikan pula sangat ditentukan oleh Sistem pendidikan yang mumpuni untuk mengembangkan kepribadian yang mempunyai karakter yang berkahlak mulia baik secara individualitas maupun secara sosial yang hendaknya menjadi titik ukur utama setiap instansi maupun institusi pendidikan yang berada di Indonesia. Menurut pendapat dari Kementrian Pendidikan dan kebudayaan Republik Indonesia bahwa ada beberapa harapan penguatan pendidikan dari penguatan pendidikan karakter yaitu : 1). Adanya pembangunan sumber daya Manusia (SDM), yang mereupakan sebagai tiang pembangunan bangsa, 2$)^{2}$. Sebagai persiapan keterampilan abad 21 yang dibutuhkan oleh anak bangsa terutama pada peserta didik yakni ; kualitas moral, literasi dasar, dan kompetensi 4C (critical thingking an problem sloving, creativity, comunication skills, and ability to work collaboratively) yang bermanfaat untuk perwujudan keunggulan gaya bersaing di generasi emas, adanya kecondongan keadaan penurunan moralitas, sikap, dan budi pukerti. Dalam dunia lembaga pedidikan, pendidikan karakter itu di aplikasikan lewat empat aspek sistem yaitu pada sistem pembelajaran, repitisi atau biasa di sebut pengulangan, penyesuaian atau biasa di sebut dengan pembiasaan, acuan, dan penegakan sikap displin.

Pendidikan pula ialah suatu upaya masyarakat dan banga dalam mempersiapkan generasi baru demi keberlangsungan kehidupan masyarakat dan bangsa yang lebih baik di masa yang akan datang. ${ }^{3}$ Para pendiri negara harusnya patut untuk menyadari bahwsannya hanya dengan menjadikan bangsa yang merdeka, bersatu, berdaulat adil dan makmurlah bangsan indoensia ini menjadi tinggi martabat dan dihormati oleh bangsa bangsa lainnya. Menurut pendapat syarif dan Rahmat bahwa keberlangsungan tersebut tandai oleh pewarisan budaya dan karakter yang telah dimiliki Masyarakat danbangsa.

\footnotetext{
${ }^{1}$ Muchtar, D., \& Suryani, A. (2019). Pendidikan Karakter Menurut Kemendikbud. Edumaspul: Jurnal Pendidikan, 3(2), 50-57. https://doi.org/10.33487/edumaspul.v3i2.142

${ }^{2}$ Kemendikbud. Konsep Dan Pedoman Penguatan Pendidikan Karakter Tingakt Sekolah Dasar Dan Sekolah Menengah Pertama.Permendikbud RI No 20 Tahun( 2018).8 - 12

3 Elihami, e., \& syahid, a. Penerapan pembelajaran pendidikan agama islam dalam membentuk karakter pribadi yang Islami. Edumaspul - jurnal pendidikan, 2(1), 79-96. (2018). Https://doi.org/10.33487/edumaspul.v2i1.17
} 
Dalam pemprosesan pendidikan budaya dan karakter bangsa, secara aktif anak bangsa atau bisa disebut sebagai anak didik dapat mengembangkan potensi dan jati dirinya. ${ }^{4}$

Menurut S. Pada abad 21 atau biasa disebut dengan globalisasi sekarang ini merupakan era keterbukaan informasi dan teknologi. Arus keterbukaan informasi berlangsung bergitu cepat, di mana semakin sempitnya batasan jarak karena dihubungkan oleh teknologi dan informasi. Pada abad ini menuntut sumber daya manusia yang berkualitas untuk menghadapi berbagi macam tantangan dan persaingan. revolusi industri abad 21 menekankan pada pola digital economi, artificial intelligence (AI), big data dan robotic. ${ }^{5}$ Terhadap hal tersebut, menyiapkan generasi berkulitas yang menguasai kompetensi abad 21 yaitu memiliki karakter yang kuat, keterampilan berpikir tingkat tinggi (Higher order thinking skills/HOTS), berpikir kritis (critical thinking), kreativitas (creativity), komunikasi (communication), dan menguasai perkembangan teknologi informasi serta mampu bersaing secara global adalah hal yang sangat penting bagi masa depan bangsa. ${ }^{6}$

Keterbukaan informasi secara global pada abad 21 menawarkan dampak positif dan dampak negatif. ${ }^{7}$ Dampak positif yang paling dirasakan adalah lahirnya individu yang padat akan wawasan dan pengetahuan, sedangkan dampak negatifnya adalah mudahnya generasi muda dalam mengakses konten-konten yang tidak bertanggung jawab seperti video porno, fakta menyebutkan bahwa sekitar $90 \%$ pelaku video porno adalah pelajar dan mahasiswa, dan mengakses berita-berita tentang kekerasan ${ }^{8}$.

Dalam pendidikan terdapat tiga ranah yang harus dikuasai oleh peserta didik, dimana dalam penerapanya diperlukan adanya keseimbangan antara tiga ranah tersebut yaitu kognitif yang berorientasi pada penguasaan ilmu pengetahuan dan teknologi,

\footnotetext{
${ }^{4}$ Syarif, i., \& rahmat, r. (2018). Penerapan model brain-based learning terhadap peningkatan karakter peserta didik kelas ii sekolah dasar. Edumaspul - jurnal pendidikan, 2(2), 87-90. Https://doi.org/10.33487/edumaspul.v2i2.13

5 Sujendra Diputra, K., Ketut Desia Tristiantari, N., Nyoman Laba Jayanta, I., Pendidikan Guru Sekolah Dasar, P., \& Pendidikan Ganesha, U. (2020). Gerakan Literasi Digital Bagi Guru-Guru Sekolah Dasar. JCES (Journal of Character Education Society), 3(1), 118-128. https://doi.org/https://doi.org/10.31764/jces.v3i1.1483

${ }^{6}$ Kanematsu, H., \& M. Barry, D. (2016). STEM And ICT Education In Intelligent Environments (Vol. 91). Springer International Publishing. Https://Doi.Org/10.1007/978-3-319-19234-5

${ }^{7}$ Sujendra Diputra, K., Ketut Desia Tristiantari, N., Nyoman Laba Jayanta, I., Pendidikan Guru Sekolah Dasar, P., \& Pendidikan Ganesha, U. (2020). Gerakan Literasi Digital Bagi Guru-Guru Sekolah Dasar. JCES (Journal of Character Education Society), 3(1), 118-128. https://doi.org/https://doi.org/10.31764/jces.v3i1.1483

${ }^{8}$ Fatoni, A. (2015). The Strategy Of Character Education In Globalization Era. International Journal Of Scientific \& Technology Research, 4(8), 112-114.
} 
psikomotor berkaitan dengan keterampilan prosedural atau mekanis, dan afektif berkaitan dengan budi pekerti atau moral.

Salah satu penerapan dan pendekatan penguatan pendidikan karakter (PPK) di sekolah dalam Permendikbud Nomor 20 Tahun 2018 tentang Penguatan Pendidikan Karakter tidak hanya dapat dilakukan melalui pendekatan di dalam kelas namun juga dapat dilaksanakan melalui budaya sekolah. Budaya sekolah merupakan suatu kegiatan yang dilakukan untuk menciptakan iklim dan lingkungan sekolah untuk mendukung penanaman nilai pendidikan karakter dalam mengatasi ruang-ruang kelas serta melibatkan seluruh sistem, struktur dan pelaku pendidikan di sekolah ${ }^{9}$. Budaya sekolah merupakan lingkungan sekolah sebagai tempat untuk saling berinteraksi secara sehat antara warga sekolah yakni kepala sekolah, guru, siswa dan lainya dan terikat oleh aturan, norma, etika dan moral yang berlaku dalam sekolah ${ }^{10}$.

Menurut Zulfiati \& Harti Pendidikan karakter melalui budaya sekolah adalah detak jantung dan suatu kebiasaan seluruh warga sekolah untuk menciptakan suasana sekolah yang kondusif, hamonis dan nyaman. Oleh karena itu warga sekolah khususnya kepala sekolah dan guru harus mampu menjadi teladan yang baik untuk peserta didik dengan memberikan contoh dalam bertingkah laku yang sesuai dengan nilai-nilai kebaikan.

Penelitian ini pernah dilakukan oleh peneliti terdahulu, penelitian yang dilakukan oleh Fitri Nur Hayati, Suyanto, dan Edhy Susantya (2020) dengan melakukan penelitian terkait "Strengthening of Religious Character Education Based on School Culture in the Indonesia Secondary School". Hasil penelitian menunjukan bahwa pelaksanaan pendidikan karakter riligius berbasis budaya sekolah dilakukan melalui pembentukan karakter berbasis nilai-nilai agama, iklim sekolah berbasis nilai-nilai agama, kegiatan ekstrakurikuler berbasis nilai-nilai agama, serta membangun hubungan antara sekolah dan masyarakat, dampak program penguatan pedidikan karakter menghasilkan dua tema yaitu tumbuhnya kesadaran beragama pada peserta didik dan tumbuhnya toleransi antar umat beragama.

\footnotetext{
9 Kemdikbud. (2017). Konsep Dan Pedoman Penguatan Pendidikan Karakter, Pusat Analisis Dan Sikronisasi Kebijakan Sekretariat Jenderal. Https://Doi.Org/10.1016/J.Smr.2019.08.005\%0Ahttp://Dx.Doi.Org/10.1016/J.Smr.2009.02.001\%0Ahttps://Scholarsh ip.Shu.Edu/Student_Scholarship

10 Zulfiati, M., \& Hartiningsih, S. (2018). Implementasi Pendidikan Karakter Melalui Budaya Sekolah Di SDN Bandungrejosari 1 Malang. Kebijakan Dan Pengembangan Pendidikan, 6, 1-181.
} 
Penelitian yang dilakukan oleh Arita Marini, Desy Safitri, dan Iskandar Muda (2018) terkait "Managing School Based on Character Building in The Context of Religious School Culture (Case in Indonesia)". Hasil penelitian berdasarkan analisis statistik menyatakan bahwa pendidikan karakter dalam budaya sekolah agama, melalui penyediaan fasilitas ibadah, upacara keagamaan dan simbol-simbol keagamaan, memiliki efek prediktif terhadap karakter keagamaan peserta didik yang digambarkan dengan kepatuhan dalam menjalankan ajaran pemeluk agama, praktik toleransi beragama terhadap orang lain dan hidup rukun dengan pemeluk agama lain. Hasil penelitian tersebut telah menunjukan bahwa penerapan penguatan pendidikan karakter memberikan pengaruh besar dalam membentuk dan memperkuat karakter peserta didik untuk menjadi insan yang bermoral. Penelitian yang dilakukan ini merupakan penelitian lanjutan dari penelitian sebelumnya.

Penelitian ini akan dilakukan di dua sekolah yaitu SD Negeri 30 Dompu dan MI AS- Salam Dompu, penelitian ini melibatkan kepala sekolah, waka kurikulum, guru kelas dan peserta didik kelas awal. Pemilihan kelas awal karena penanaman nilai-nilai pendidikan karakter sangat penting untuk ditanamkan sejak dini, untuk membentuk kebiasaan positif peserta didik sehingga dapat menyatu dalam diri peserta didik dan menjadi karakter yang permanen. Hal ini selaras dengan pendapat Sudaryanti yang mengatakan bahwa pendidikan karakter sebaiknya diterapkan sejak dini karena dapat membantu mengantarkan peserta didik pada matang dalam mengelola emosi. Kecerdasan emosi merupakan bekal penting bagi peserta didik untuk menyongsong masa depan yang penuh tantangan ${ }^{11}$.

Berdasarkan permasalahan yang terjadi di lapangan, penelitian ini memfokuskan pada tiga nilai karakter utama yaitu religius, nasionalis dan mandiri. Ketiga nilai karakter tersebut dipilih karena nilai karakter tersebut masih kurang nampak pada proses pendidikan yang berlangsung.

Berdasarkan pemaparan di atas sangat penting implementasi pendidikan karakter diterapkan di sekolah-sekolah sebagai upaya untuk menyadarkan peserta didik akan pentingnya mematuhi aturan yang berlaku serta memiliki komitmen untuk terus melaksanakan nilai-nilai kebaikan dalam kehidupannya. Maka dari itu peneliti tertarik

${ }^{11}$ Sudaryanti. (2015). Pentingnya Pendidikan Karakter Bagi Anak Usia Dini. Jurnal Pendidikan Anak, 1(1), 11-20. Https://Doi.Org/10.21831/Jpa.V1i1.2902 
untuk melakukan penelitian terkait "Implementasi Nilai-Nilai Pendidikan Karakter

\section{Melalui Budaya Sekolah Di SD Negeri 26 Dompu Dan MI As - Salam Dompu”}

Peneliti merumuskan masalah yang akan diteliti dalam penelitian ini ialah Bagaimana perencanaan pendidikan karakter melalui budaya sekolah di SD Negeri 26 Dompu dan MI As - Salam Dompu ? dan Berdasarkan rumusan masalah tersebut maka tujuan penelitiannya adalah Mendeskripsikan percenanaan pendidikan karakter melalui budaya sekolah di SD Negeri 26 Dompu dan MI As - Salam Dompu

\section{METODELOGI PENELITIAN}

Penelitian ini menggunakan pendekatan kualitatif deskriptif merupakan proses penelitian yang digunakan untuk meneliti fenomena sosial dan masalah sosial yang dilakukan pada kondisi yang alamiah ${ }^{12}$. Pada pendekatan ini peneliti membuat suatu gambaran kompleks yang menghasilkan data deskriptif berupa kata-kata maupun lisan dari responden maupun dari perilaku yang di amati. Penelitian ini mendeskripsikan tentang implementasi nilai-nilai pendidikan karakter melalui budaya sekolah di SDN 26 Dompu dan MI As - Salam Dompu.

Jenis penelitian studi multi kasus (multycase studies) merupakan studi yang berusaha untuk mengambil data yang mendalam dan terperinci dari narasumber. Studi kasus (multycase studies) dilakukan ketika peneliti mempelajari atau meneliti lebih dari satu kasus ${ }^{13}$. Dalam penelitian ini studi multi kasus dimulai dari kasus tunggal (kasus pertama), kemudian dilanjutkan pada lintas kasus tentang implementasi nilai-nilai pendidikan karakter melalui budaya sekolah yang dilakukan di SDN 26 Dompu dan MI As - Salam Dompu

Penelitian dilaksanakan di dua sekolah yaitu di SD Negeri 26 Dompu dan MI AS Salam Dompu. Dengan sumber data primer dan sekunder yakni data yang secaca langsung memberikan informasi kepada peneliti (Sugiyono, 2016).

Teknik pengumpulan data dengan cara wawancara, observasi dan Dokumentasi.

1. Wawancara merupakan teknik pengumpulan data dalam penelitian yang dimana peneliti saling bertatap muka secara langsung dengan narasumber atau informan

${ }^{12}$ Sugiyono. (2016). Metode Penelitian Pendidikan Pendekatan Kuantitatif, Kualitatif, Dan R\&D. Alfabeta. Alfabeta.

${ }^{13}$ Darmadi, H. (2014). Metode Penelitian Pendidikan Dan Sosial Teori Konsep Dasar Dan Implementasi. 
yang di teliti. Teknik wawancara memungkinkan peneliti dengan informan melakukan kegiatan tanya jawab secara interaktif maupun secara sepihak misanya dari peneliti saja.

Tabel 2.1 Kisi - Kisi Pedoman Wawancara Kepala Sekolah Dan Guru

\begin{tabular}{lll}
\hline No. & \multicolumn{1}{c}{ Aspek } & \multicolumn{1}{c}{ Indikator } \\
\hline 1. & Perencanaan pendidikan & a. Pemahaman tentang pendidikan karakter \\
& karakter & $\begin{array}{l}\text { b. Perencanaan program pendidikan karakter } \\
\text { melalui budaya sekolah }\end{array}$ \\
\hline
\end{tabular}

\section{Observasi}

Observasi merupakan teknik dengan menggunakan pengamatan atau penglihatan dan pencatatan tentang perilaku dan aktivitas dalam penelitian. Observasi akan lebih efektif jika informasi yang hendak diambil berupa fakta alami, tingkah laku alami, dan hasil kerja informan dalam situasi alami (Sugiyono, 2016).

Tabel 2.2 Kisi-Kisi Observasi Penelitian

\begin{tabular}{|c|c|c|}
\hline No. & Aspek & Indikator \\
\hline 1. & $\begin{array}{l}\text { Lingkungan } \\
\text { sekolah }\end{array}$ & $\begin{array}{l}\text { a. Suasana lingkungan sekolah } \\
\text { b. Tulisan-tulisan di diding sekolah untuk meningkatkan } \\
\text { karakter siswa }\end{array}$ \\
\hline 2. & Budaya sekolah & $\begin{array}{l}\text { a.Peserta didik dalam menerapkan budaya sekolah } \\
\text { b. Perilaku peserta didik terhadap semua warga sekolah } \\
\text { c. Kebiasaan peserta didik di lingkungan sekolah } \\
\text { d. Pelaksanaan pendidikan karakter melalui budaya } \\
\text { sekolah }\end{array}$ \\
\hline
\end{tabular}

\section{Dokumentasi}

Dokumentasi adalah salah satu tekhnik pengumpulan data yang dilakukan dengan pengumpulan data berupa dokumen. Dokumen biasanya berbentuk tulisan contohnya catatan harian, gambar atau foto, dan karya-karya monumental. Hasil penelitian dari observasi dan wawancara akan lebih kredibel atau dapat dipercaya jika didukung oleh dokumen yang berbentuk tulisan, foto-foto atau karya tulis (Sugiyono, 2016).

Tabel 2.3 Dokumentasi Penelitian

\begin{tabular}{ccl}
\hline No. & \multicolumn{1}{c}{ Aspek } & \multicolumn{1}{c}{ Indikator } \\
\hline 1. $\cdot$ Dokumen & a. Dokumen perencanaan budaya sekolah \\
& & b. Dokumen kegiatan pendidikan karakter \\
& & c. Dokumen pedoman atau penunjang pendidikan \\
& & karakter \\
\hline
\end{tabular}




\section{PEMBAHASAN DAN HASIL}

\section{Implementasi pendidikan karakter}

\section{Pengertian implementasi}

Kata implementasi berasa dari bahasa Inggris yaitu to implement yang berarti mengimplementasikan ${ }^{14}$. Joko Susilo menyatakan bahwa implementasi adalah suatu penerapan ide konsep, kebijakan, atau inovasi dalam tindakan praktis sehingga dapat memberikan perubahan dalam pengetahuan, keterampilan, dan sikap. ${ }^{15}$

Implementasi merupakan penyediaan sarana untuk melaksanakan suatu kegiatan yang dapat memberikan dampak dari metode atau kegiatan yang dilakukan. Dalam oxford advance learner's dictionary implementasi merupakan "put something into effect" (menerapkan sesuatu yang dapat memberikan suatu dampak. ${ }^{16}$ Oleh karena itu implementasi merupakan penerapan suatu pendekatan, metode atau kegiatan yang dilakukan secara terus menerus sehingga memberikan perubahan terhadap pengetahuan, keterampilan dan sikap atau karakter peserta didik sesuai dengan tujuan Pendidikan Nasional di SDN 26 Dompu dan MI AS - Salam Dopmu.

\section{Pengetian pendidikan karakter}

Istilah karakter yang dikemukakan oleh pencetus pendidikan karakter pertama F.W. Foerster menyatakan karakter merupakan sesuatu yang mengualifikasi seseorang pribadi. Karakter menjadi identitas, ciri, sifat yang tetap dalam mengatasi pengalaman kehidupan yang selalu berubah. Karakter adalah seperangkat nilai yang telah menjadi kebiasaan hidup sehingga menjadi sifat tetap dalam diri seseorang, misalnya kerja keras, pantang menyerah, jujur, sederhana, dan lain sebagainya. Dewantara menyatakan bahwa pendidikan karakter merupakan bagian penting dari pendidikan secara keseluruhan yang bertujuan agar peserta didik mampu menguasai diri sehingga dapat mengilangkan dan dapat mengalahkan fitrah manusia yang tidak sesuai. ${ }^{17}$ Selaras dengan pendapat dari Lickano yang menjelaskan bahwa pendidikan karakter merupakan upaya sungguh-

\footnotetext{
${ }^{14}$ Lestari, D. Y., Kusnandar, I., \& Muhafidin, D. (2020). Pengaruh Implementasi Kebijakan Terhadap Transparansi Pengadaan Barang / Jasa Pemerintah Secara Elektronik Di Kabupaten Pangandaran. Dinamika: Jurnal Ilmiah Ilmu Administrasi Negara, 7(1), 180-193.

${ }^{15}$ Sosial, B. R. (2015). Implemenetasi Pembelajaran Pendidikan Agama Islam Berwawasan Rekonstruk. 6(November).

${ }^{16}$ Heri Gunawan. (2012). Pendidikan Karakter Konsep Dan Implementasi. Alfabeta.

${ }^{17}$ Hakam, K. A. (2018). Tradition Of Value Education Implementation In Indonesian Primary Schools. Journal Of Social Studies Education Research, 9(4), 295-318. Https://Doi.Org/10.17499/Jsser.98315
} 
sungguh dalam membantu peserta didik untuk dapat memahami, menyadari dan bertindak sesuai dengan landasan nilai-nilai etika. ${ }^{18}$

Pendidikan karakter sangat erat kaitanya dengan sekolah, Anni Lockword (Wiyani, 2013) menyatakan bahwa pendidikan karakter sebagai aktivitas berbasis sekolah yang mengungkap secara sistematis bentuk perilaku dari peserta didik. Pendidikan karakter dihubungkan dengan setiap rencana sekolah, yang dirancang bersama lembaga masyarakat lain untuk membentuk secara langsung dan sistematis perilaku generasi bangsa. Dengan demikian pelaksanaan pendidikan karakter merupakan bagian yang terintegrasi dengan manajemen pendidikan sekolah. ${ }^{19}$

jadi pendidikan karakter merupakan suatu upaya yang dilakukan secara sistematis dan terus menerus oleh sekolah untuk menanamkan nilai-nilai karakter pada peserta didik agar memiliki sikap dan perilaku luhur dalam kehidupan sehari-hari, baik dalam berinteraksi dengan Tuhan, sesama manusia dan lingkungan hidupanya sesuai dengan filsafah Pancasila.

\section{Tujuan Pendidikan Karakter}

Tujuan pendidikan karakter menurut Battistick adalah untuk menumbuhkan kapasitas peserta didik dalam memahami nilai-nilai moral untuk diterapkan dalam bentuk tindakan yang baik dan tebaik serta untuk memahami tujuan hidup yang sebenarnya. Selain itu menurut Nurhasanah dan Nida pendidikan karakter juga bertujuan atau berperan untuk meningkatkan kualitas hasil penyelenggaraan pendidikan di sekolah yang bermuara pada pencapaian pembentukan karakter dan keluhuran budi pekerti peserta didik secara menyeluruh, terpadu dan seimbang sesuai standar kompetensi yang berlaku. $^{20}$

\section{Prinsip Pendidikan Karakter}

${ }^{18}$ Hayati, F. N., Suyatno, S., \& Susatya, E. (2020). Strengthening Of Religious Character Education Based On School Culture In The Indonesian Secondary School. The European Educational Researcher, 3(3), 87-100. Https://Doi.Org/10.31757/Euer.331

${ }^{19}$ Wiyani, N. A. (2013). Membumikan Pendidikan Karakter di SD. Ar-Ruzz Media.

20 Zurqoni, Retnawati, H., Arlinwibowo, J., \& Apino, E. (2018). Strategy and implementation of character education in senior high schools and vocational high schools. Journal of Social Studies Education Research, 9(3), 370397. https://doi.org/10.17499/jsser.01008 
Implementasi penguatan pendidikan karakter (PPK) dalam Peraturan Presiden Nomor 87

Tahun 2017 dilaksanakan dengan menggunakan prinsip sebagai berikut:

1. Penguatan pendidikan karakter berorientasi dalam mengembangkan potensi peserta didik yang dilakukan secara menyeluruh dan terpadu

2. Keteladanan dalam penerapan pendidikan karakter pada masing-masing lingkungan pendidikan atau sekolah, dan

3. Dilakukan melalui pembiasaan dan sepanjang waktu dalam kehidupan sehari-hari.

\section{Nilai - nilai pendidikan karakter}

Sebagai wujud Gerakan Nasional Revolusi Mental (GNRM) pendidikan karakter menjadi jantung hati dan poros pelaksanaan pendidikan nasional, baik di jenjang pendidikan dasar maupun perguruan tinggi. Beriku ini lima nilai utama dalam penguatan pendidikan karakter (PPK) (Kemdikbud, 2017):

1. Religius

2. Nasionalis

3. Mandiri

4. Gotong royo

5. Intgegrasi

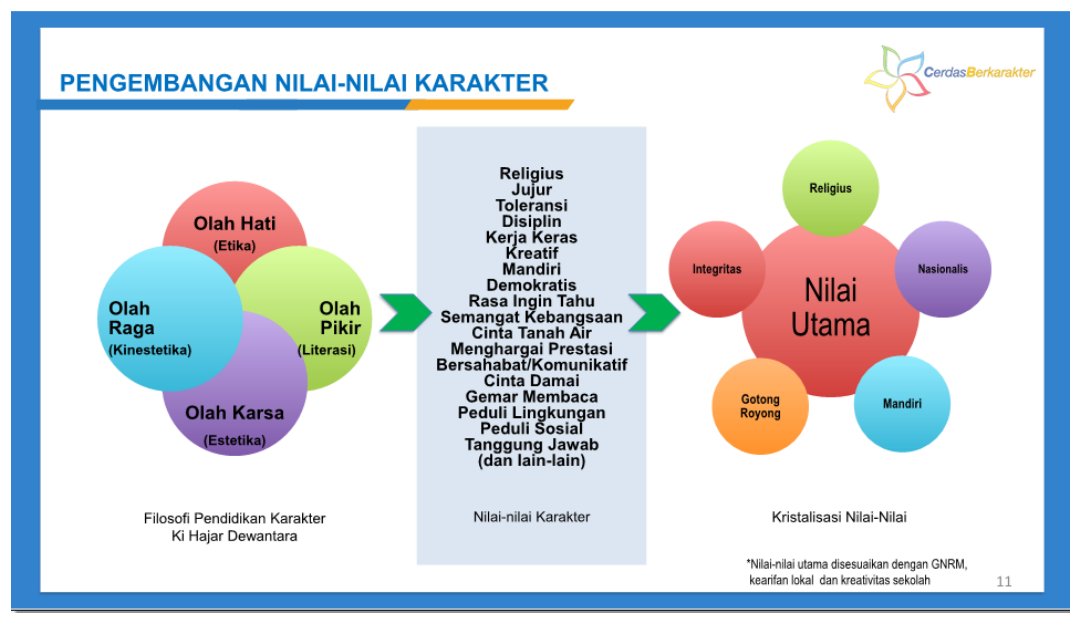

Gambar 3.1 pengembangan Nilai - nilai karakter

Sumber : https://cerdasberkarakter.kemdikbud.go.id/

Lima nilai utama penguatan pendidikan karakter masing-masing memiliki sub nilai yang berbeda untuk diterapkan di sekolah. Agar nilai-nilai karakter dapat diterapkan dengan maksimal, semua komponen pemangku pendidikan harus dilibatkan, termaksud komponen-komponen pendidikan itu sendiri yaitu kurikulum, pengelolaan mata 
pelajaran, pengelolaan sekolah, kegiatan ko-kurikuler maupun ekstrakurikuler. Penanaman nilai-nilai karakter di sekolah membutuhkan teladan atau contoh nyata bagi peserta didik untuk mempermudah dan mengefektifkan pendidikan karakter. Kepala sekolah, guru dan karyawan sekolah harus mampu menjadi teladan atau model untuk peserta didik.

Langkah-langkah pelaksanaan penguatan pendidikan karakter (PPK) melalui budaya sekolah (Kemdikbud, 2017) dapat dilaksanakan sebagai berikut: ${ }^{21}$

a. Menentukan nilai utama penguatan pendidikan karakter (PPK)

Sekolah menentukan nilai utama yang akan menjadi fokus dalam pengembangan pembentukan dan penguatan karakter di lingkungan sekolah. Pemilihan nilai utama bersamaan dengan dirumuskan nilai pendukung yang relavan dilakukan melalui kegiatan diskusi, musyawarah, dan dialog dengan seluruh pemangku kepentingan yaitu kepala sekolah, pendidik, tenaga kependidikan, komite sekolah dan peserta didik. Seluruh pemangku kepentingan menyepakati nilai utama yang menjadi prioritas serta nilai pendukung, dan jalinan antar nilai dalam membentuk karakter warga sekolah, dan tertuang dalam visi misi sekolah.

Nilai utama yang dipilih oleh sekolah menjadi fokus utama dalam proses pengembangan budaya dan menjadi identitas sekolah. Seluruh kegiatan, program serta pengembangan karakter di sekolah berpusat pada nilai utama dan berlaku bagi seluruh warga sekolah.

b. Menyusun Jadwal Harian/Mingguan

Sekolah menyusun jadwal kegiatan harian atau mingguan untuk memperkuat nilainilai utama pendidikan karakter yang telah dipilih sebagai upaya penguatan yang dilakukan melalui pembiasaan dan terintegrasi dalam kegiatan sehari-hari.

c. Evalusasi Peraturan Sekolah

Budaya sekolah yang baik dapat terlihat pada manajemen sekolah yang mengarah pada pembentukan dan penguatan karakter. Sekolah harus melakukan koreksi dan evaluasi atas berbagai peraturan yang telah diterapkan serta menyelaraskan dengan nilai-

21 Kemdikbud. (2017). Konsep Dan Pedoman Penguatan Pendidikan Karakter, Pusat Analisis Dan $\begin{array}{lllll}\text { Sikronisasi Kebijakan } & \text { Sekretariat } & \text { Jenderal. } & \text { 17(5), } & 684-694 .\end{array}$ Https://Doi.Org/10.1016/J.Smr.2019.08.005\%0Ahttp://Dx.Doi.Org/10.1016/J.Smr.2009.02.001\%0Ahttps://Scholarsh ip.Shu.Edu/Student_Scholarship 
nilai revolusi mental yang ingin diarahkan pada penguatan pendidikan karakter. Evaluasai peraturan sekolah dilaksanakan dengan tujuan untuk melihat apakah peraturan sekolah yang telah diterapkan mampu membentuk karakter peserta didik atau justru malah melemahkanya. Upaya telaah, analisis, dan revisi sangat penting untuk dapat mengahdirkan kultur pembentukan dan penguatan karakter yang mampu mendorong peserta didik belajar dari pengalaman yang mereka lalui atau rasakan sesuai dengan tahapan perkembangannya. Contoh peraturan yang dievaluasi berkaitan dengan peraturan kedisiplinan atau tata tertib sekolah, penerapan kebijakan kriteria ketuntasan minimal (KKM).

\section{d. Pengembangan Tradisi Sekolah}

Sekolah memiliki tradisi yang harus dikembangkan dan diperkuat sebagai upaya penguatan pendidikan karakter berbasis budaya sekolah. Selain mengembangkan tradisi yang baik, sekolah juga harus mengevaluasi dan merefleksi terkait tradisi yang sudah ada masih relavan dengan kondisi zaman sekarang atau harus direvisi kembali, dengan tujuan agar mampu menjawab berbagai tantangan yang sedang berkembang, serta selaras dengan upaya penguatan pendidikan karakter di sekolah tersebut.

e. Pengembangan Kegiatan Kokurikuler

Kegiatan kokurikuler dengan intrakurikuler harus relavan dengan target pencapaian indikator setiap mata pelajaran, sehingga tujuan pengembangan dapat tercapai. Kegiatan tersebut telah di susun oleh pendidik atau guru dalam silabus dan RPP pada awal tahun pembelajaran yang dapat dilaksanakan baik di dalam lingkungan kelas maupun di luar kelas.

\section{f. Ekstrakurikuler (Wajib dan Pilihan)}

Kegiatan ektrakurikuler bertujuan untuk mengembangkan kepribadian dan bakat peserta didik, sesuai dengan minat dan kemaunya. Ektrakurikuler dibagi menjadi dua yaitu ektrakurikuler wajib yang harus direalisasikan karena merupakan tuntutan kurikulum yang berlaku yaitu pramuka, dan ektrakurikuler pilihan merupakan kegiatan pengembangan yangbdikembangkan oleh masing-masing satuan pendidikan. Seluruh kegiatan ektrakurikuler yang dikembangkan harus memuat dan menegaskan nilai-nilai karakter melalui setiap kegiatan yang dilakukan. Secara implisit kegiatan ektrakurikuler telah mengandung nilai-nilai karakter, namun tetap harus diungkap secara eksplisit dan 
ditegaskan kembali pada akhir kegiatan, agar peserta didik paham akan nilai-nilai kebaikan tersebut.

\section{BUDAYA SEKOLAH}

\section{Pengertian Budaya Sekolah}

Menurut Segala budaya menggambarkan cara manusia melakukan segala sesuatu, maka dari itu budaya merupakan suatu konsep yang dapat membangkitkan minat dan berkaitan dengan cara manusia itu hidup, belajar berfikir, mempercayai dan merasa serta mengusahakan apa yang sesuai dengan budayanya. ${ }^{22}$

Maka dari itu budaya dapat dikatakan sebagai suatu kebiasaan dalam bentuk perilaku, nilai-nilai, cara hidup serta sikap hidup dalam linngkungan dan di wariskan secara turun temurun dari generasi ke generasi. Budaya sekolah menurut Muhaimin merupakan kehidupan di lingkungan sekolah yang tenang dan reflektif sesuai dengan yang dibangun dari hasil pertemuan antara nilai-nilai (values) yang di anut dan diterapkan oleh pemimpin sekolah yakni kepala sekolah, dan dibantu oleh pendidik dan tenaga kependidikan. ${ }^{23}$ Selaras dengan Deal dan Petterson yang menyatakan bahwa budaya sekolah merupakan sekumpulan nilai yang melandasi perilaku, kebiasaan, trasidi, upacara yang diterapkan oleh kepala sekolah, pendidik, karyawan sekolah dan seluruh warga sekolah. ${ }^{24}$

\section{Manfaat Budaya Sekolah}

Pengembangan budaya sekolah yang kuat, intim, kondusif dan betanggung jawab dapat memberikan banyak manfaat bagi seluruh warga sekolah. Manfaat pengembangan budaya sekolah tidak hanya di rasakan oleh warga sekolah namun dapat dirasakan oleh semua pihak dimana saja karena dibentuk dengan norma pribadi tidak menggunakan aturan yang kaku dengan berbagai hukuman jika terjadi pelanggaran. ${ }^{25}$ Manfaat pengembangan budaya sekolah sebagai berikut:

22 Eva, M. (2016). Pengembangan Budaya Sekolah. Tarbawi, 2(02), 86-96. Https://Media.Neliti.Com/Media/Publications/Publications/256481-Pengembangan-Budaya-Sekolah-1bf3dd81.Pdf

23 Hapudin, M. S. (2019). Implementasi Pendidikan Karakter Melalui Budaya Sekolah. Journal Of Teching And Learning Research, 1(2), 121-130.

${ }^{24}$ Peterson, K. D., \& Deal, T. E. (2002). The Shaping School Culture Fieldbook. The Jossey-Bass Education Series. Https://Files.Eric.Ed.Gov/Fulltext/ED479930.Pdf

25 Eva, M. (2016). Pengembangan Budaya Sekolah. Tarbawi, 2(02), 86-96. Https://Media.Neliti.Com/Media/Publications/Publications/256481-Pengembangan-Budaya-Sekolah-1bf3dd81.Pdf 
1. Dapat menjamin kualitas kerja yang lebih baik

2. Memiliki sikap yang lebih terbuka dan transparan

3. Memperluas jaringan komunikasi dari segala arah

4. Mampu menciptakan kebersamaan dan rasa saling memiliki yang tinggi

5. Jika menemukan kesalahan akan segera diperbaiki

6. Meningkatkan solidaritas dan rasa kekeluargaan

7. Mampu mengembangkan warga sekolah yang dapat menghadapi berbagi macam tuntutan dan tatangan perkembangan zaman atau IPTEK.

\section{HASIL PEMBAHASAN}

Berdasarkan hasil penelitian yang telah dilakukan oleh penelitian terkait topik yang dibahas :

\section{Tabel 3. 1 Kerangka berpikir}

\section{KONDISI IDEAL}

Undang-Undang No. 20 Tahun 2003 tentang Sistem Pendidikan Nasional, betujuan untuk berkembangnya potensi peserta didik agar menjadi manusia yang beriman dan bertakwa kepada Tuhan Yang Maha Esa, berakhlak mulia, sehat, berilmu, cakap, kreatif, mandiri, dan menjadi warga Negara yang demokratis serta bertanggung jawab

\section{KONDISI LAPANGAN}

1. Kurang patuh melaksanakan ajaran agama yang di anutnya

2. Masih bergantung dengan orang lain

3. Tidak disiplin ketika melaksanakan upaca bendera, dan masih banyak yang tidak mengikuti peraturan dan hukum yang berlaku

Perencanaan penguatan pendidikan karakter di sekolah dasr ?

\section{Budaya sekolah ?}

Perencanaan penguatan pendidikan karakter melalui budaya sekolah di SD Negeri 26 Dompu dan MI As - Salam Dompu

Penguatan Pendidikan Karakter Nilai Religius, Nasionalis, dan Mandiri

Penelitian ini akan dilakukan di dua sekolah yaitu SD Negeri 26 Dompu dan SD MI As -Salam Dompu, penelitian ini melibatkan kepala sekolah, waka kurikulum, guru kelas dan peserta didik kelas awal. Pemilihan kelas awal karena penanaman nilai-nilai 
pendidikan karakter sangat penting untuk ditanamkan sejak dini, untuk membentuk kebiasaan positif peserta didik sehingga dapat menyatu dalam diri peserta didik dan menjadi karakter yang permanen. Hal ini selaras dengan pendapat Sudaryanti yang mengatakan bahwa pendidikan karakter sebaiknya diterapkan sejak dini karena dapat membantu mengantarkan peserta didik pada matang dalam mengelola emosi. Kecerdasan emosi merupakan bekal penting bagi peserta didik untuk menyongsong masa depan yang penuh tantangan (Sudaryanti, 2015). ${ }^{26}$

SD Negeri 26 Dompu merupakan salah satu sekolah tertua yang terletak di Desa O’o Timur Kabupaten Dompu NTB. Sekolah ini merupakan sekolah umum yang mengutamakan nilai religus dalam pendidikanya. Sekolah ini memiliki banyak prestasi baik dalam bidang akademik maupun non akademik. Dalam bidang akademik peserta didik SDN 26 Dompu mampu meraih prestasi tingkat propinsi dalam bidang cerdas cermat. Dalam bidang non akademik SD Negeri 26 Dompu memiliki banyak prestasi salah satunya yaitu sekolah ini merupakan sekolah yang dinobatkan sebagai sekolah sehat terbaik di Kabupaten Dompu.

Beradasarkan hasil wawancara yang dilakukan dengan Kepala SD Negeri 26 Dompu, sekolah ini merupakan sekolah ramah anak yang sehat dan menyenangkan bagi peserta didik dengan mengutamakan nilai karakter religius dalam penanamkan pendidikan karakter di sekolah dan nilai karakter pendukung lainya. Pembiasan yang dilakukan secara terus menerus adalah membiasakan 5S (senyum, salam, sapa, sopan dan santun), setiap pagi akan ada guru piket dan guru lainya yang berdiri di depan sekolah untuk menyapa peserta didik. Selain itu setiap hari senin pagi sekolah selalu melakukan upacara untuk menanamkan nilai karakter nasionalis berkaitan dengan cinta tahan air. Peserta didik dibiasakan secara mandiri untuk selalu menjaga kebersihan dan kenyamanan di lingkungan sekolah.

Sekolah juga membudayakan literasi pada peserta didik, dengan disediakanya sudut baca di lingkungan sekolah maupun dalam kelas. Sebelum memasuki ruang kelas peserta didik akan berbaris dengan rapi di depan kelas tanpa arahan dari guru karena telah dibiasakan sejak awal. Sebelum memulai pembelajaran penanamkan karakter dilakukan dengan membiasakan peserta didik membaca buku 15 menit dan berdo'a. Dalam upaya

${ }^{26}$ Sudaryanti. (2015). Pentingnya Pendidikan Karakter Bagi Anak Usia Dini. Jurnal Pendidikan Anak, 1(1), 11-20. Https://Doi.Org/10.21831/Jpa.V1i1.2902 
melakukan penanaman nilai karakter utama sekolah yaitu religius, sekolah membiasakan setiap hari jum'at selalu ada kegiatan imtak dimana peserta didik akan mendengarkan ceramah yang disampaikan oleh guru.

SD Negeri 26 Dompu mewajbkan peserta didik untuk mengikuti kegiatan ekstrakurikuler pramuka dan diniah serta ekstrakurikuler pilihan dilakukan pada waktu sore hari. Selain itu peserta didik menggunakan waktu belajar dengan bersunguh-ungguh untuk menggapai prestasi dan mampu menyelesaikan permasalahanya sendiri. Terdapat juga tulisan-tulisan dan poster di setiap dinding sekolah untuk meningkatkan dan memperkuat karakter peserta didik. Semua kegiatan pendidikan dan fasilitas yang disediakan di sekolah bertujuan untuk menunjang pendidikan karakter pada peserta didik. Melalui pembiasaan yang dilakukan oleh sekolah, karakter yang paling menonjol yang ditanamkan melalui budaya sekolah adalah karakter religius, nasionalis, dan mandiri.

Sekolah selanjutnya adalah MI As - salam Dompu merupakan salah satu Sekolah madrasah ibtidaiyah yang juga menyediakan jenjang pendidikan TK Islam Terpadu dan SMP Islam Terpadu. MI As - salam merupakan sekolah yang didirikan pada tahun 2010 dan termaksud sekolah yang baru tetapi sudah mampu menarik banyak perhatian masyarakat karena terkenal dengan sekolah yang mengutamakan pendidikan Aqidah, Akhlak dan Ibadah. Sekolah ini menjalankan pendidikan sesuai dengan visi dan misi sekolah dengan visi sekolah adalah menjadikan lembaga pendidikan bermutu dan kompetitif, yang mampu mencetak generasi Islam bermanhaj Salafus Sholeh yang bertakwa, cerdas, keratif dan inovatif.

Keunggulan MI As - salam adalah peserta didik memiliki target hafalan dan harus menghafal menghafalAl-Qur'an 5 juz, memahami ilmu syar'i (aqidah, fiqih, adab dan akhlak), menguasai do'a dan praktek ibadah yang benar, menghafal 100 hadits mutiara pilihan serta keunggulan lain dari sekolah adalah menyediakan lingkungan sekolah yang ramah anak atau nyaman dengan fasilitas yang memadai. Oleh karena itu seluruh warga sekolah berusaha menciptakan lingkungan sekolah yang nyaman, kondusif dan menyenangkan.

Berdasarkan hasil wawancara dengan Kepala MI As - salam Dompu, sebagai upaya untuk meningkatkan penanaman karakter pada peserta didik sekolah bekerjasama dengan orang tua untuk memberikan pembiasaan yang dilakukan di sekolah dan di rumah. Pembiasaan dimulai dari peserta didik bangun tidur hingga peserta didik tidur kembali. 
Pembiasaan yang dilakukan adalah dengan mengajarkan kepada peserta didik adab di sekolah dan di dalam kelas serta adab di rumah bersama orang tua yang harus di hafalkan dan dipraktekan oleh peserta didik dalam kehidupan sehari-hari. Selain itu peserta didik dibiasakan untuk memiliki rasa tanggung jawab dan mandiri ketika mereka menggunakan fasilitas yang tersedia di sekolah untuk menjaga lingkungan sekolah agar tetap bersih dan nyaman.

Madarasah bitidaiyah harus membiasakan untuk menyapa peserta didik setiap pagi ketika peserta didik datang ke sekolah dengan menyediakan guru piket yang akan berdiri di depan sekolah. Guru piket akan menyapa dan bertanya berkaitan dengan bagaimana kabar peserta didik, apakah tadi mengerjakan sholat subuh dan pertanyaan lainya. Dan setelah itu ada kegiatan rutinitas ditiap harinya yakni melakukan MAROSIM , memuroj'ah hafalan -hafalan anak -anak dari kelas I sampai dengan kelas VI . pembiasaan ini juga dilakukan di dalam kelas sebelum pembelajaran dimulai yang akan di tanyakan oleh guru kelas.

Penanaman nilai karakter pada peserta didik telah ditanamkan di sekolah ini dengan maksimal, terdapat nilai karakter yang lebih ditekankan dan menojol adalah religius, nasionalis dan mandiri. Pembiasaaan lainya adalah, dibiasakan baris berbaris di depan kelas, sebelum jam pembelajaran dimulai peserta didik akan melakukan zikir pagi bersama, muroj'ah (mengulang) hafalan doa-doa. Kemudian guru kelas akan memberikan pertanyaan berkaitan dengan bagaimana adab di sekolah dan di dalam kelas, bagaimana adab dengan teman-teman dan adab dengan orang tua di rumah.

Berdasarkan permasalahan yang terjadi di lapangan, penelitian ini memfokuskan pada tiga nilai karakter utama yaitu religius, nasionalis dan mandiri. Ketiga nilai karakter tersebut dipilih karena nilai karakter tersebut masih kurang nampak pada proses pendidikan yang berlangsung. Karakter religius sangat penting untuk diterapkan sejak dini pada peserta didik untuk menumbuhkan karakter positif melalui ajaran agama yang menjadi pedoman hidup seluruh umat manusia. Nilai karakter religius mencerminkan keberimanan kepada Tuhan yang dapat mengajarkan pengendalian diri serta aturanaturan dalam kehidupan yang sesuai dengan ajaran agama. 


\section{SIMPULAN}

Berdasarkan hasil penelitian yang dilakukan di dua sekolah yaitu SD Negeri 30 Dompu dan MI AS- Salam Dompu yang terkait "Implementasi Nilai-Nilai Pendidikan Karakter Melalui Budaya Sekolah Di SD Negeri 26 Dompu Dan MI As - Salam Dompu”. Berdasarkan permasalahan yang terjadi di lapangan, penelitian ini memfokuskan pada tiga nilai karakter utama yaitu religius, nasionalis dan mandiri. Ketiga nilai karakter tersebut dipilih karena nilai karakter tersebut masih kurang nampak pada proses pendidikan yang berlangsung. Untuk pemaparan di atas sangat penting implementasi pendidikan karakter diterapkan di sekolah-sekolah sebagai upaya untuk menyadarkan peserta didik akan pentingnya mematuhi aturan yang berlaku serta memiliki komitmen untuk terus melaksanakan nilai-nilai kebaikan dalam kehidupannya. Dan mendapatkan tujuan penelitiannya adalah Mendeskripsikan percenanaan pendidikan karakter melalui budaya sekolah di SD Negeri 26 Dompu dan MI As - Salam Dompu.

\section{DAFTAR PUSTAKA}

Darmadi, H. Metode Penelitian Pendidikan Dan Sosial Teori Konsep Dasar Dan Implementasi. Alfabeta. (2014).

Elihami, e., \& syahid, a. Penerapan pembelajaran pendidikan agama islam dalam membentuk karakter pribadi yang Islami. Edumaspul - jurnal pendidikan, 2(1), 79-96. (2018). Https://doi.org/10.33487/edumaspul.v2i1.17

Eva, M. Pengembangan Budaya Sekolah. Tarbawi, 2(02), 86-96. Https://Media.Neliti.Com/Media/Publications/Publications/256481-

Pengembangan-Budaya-Sekolah-1bf3dd81.Pdf. (2016).

Fatoni, A. The Strategy Of Character Education In Globalization Era. International Journal Of Scientific \& Technology Research, 4(8), 112-114. (2015).

Hayati, F. N., Suyatno, S., \& Susatya, E. Strengthening Of Religious Character Education Based On School Culture In The Indonesian Secondary School. The European Educational Researcher, 3(3), 87-100. (2020). Https://Doi.Org/10.31757/Euer.331

Hakam, K. A. Tradition Of Value Education Implementation In Indonesian Primary Schools. Journal Of Social Studies Education Research, 9(4), 295-318. (2018). Https://Doi.Org/10.17499/Jsser.98315

Heri Gunawan. Pendidikan Karakter Konsep Dan Implementasi. Alfabeta. (2012). 
Hapudin, M. S. Implementasi Pendidikan Karakter Melalui Budaya Sekolah. Journal Of Teching And Learning Research, 1(2), 121-130. (2019).

Kanematsu, H., \& M. Barry, D. STEM And ICT Education In Intelligent Environments (Vol. 91). Springer International Publishing. Https://Doi.Org/10.1007/978-3-31919234-5. (2016).

Kemendikbud. Konsep Dan Pedoman Penguatan Pendidikan Karakter Tingakt Sekolah Dasar Dan Sekolah Menengah Pertama.Permendikbud RI No 20 Tahun( 2018).8 - 12 Kemdikbud. Konsep Dan Pedoman Penguatan Pendidikan Karakter, Pusat Analisis Dan Sikronisasi Kebijakan Sekretariat Jenderal. 17(5), 684-694. Https://Doi.Org/10.1016/J.Smr.2019.08.005\%0Ahttp://Dx.Doi.Org/10.1016/J.Smr. 2009.02.001\%0Ahttps://Scholarship.Shu.Edu/Student_Scholarship. (2017).

Lestari, D. Y., Kusnandar, I., \& Muhafidin, D. Pengaruh Implementasi Kebijakan Terhadap Transparansi Pengadaan Barang / Jasa Pemerintah Secara Elektronik Di Kabupaten Pangandaran. Dinamika : Jurnal Ilmiah Ilmu Administrasi Negara, 7(1), 180-193. (2020).

Muchtar, D., \& Suryani, A. Pendidikan Karakter Menurut Kemendikbud. Edumaspul: Jurnal Pendidikan, 3(2), 50-57. https://doi.org/10.33487/edumaspul.v3i2.142 (2019).

Peterson, K. D., \& Deal, T. E. The Shaping School Culture Fieldbook. The Jossey-Bass Education Series. Https://Files.Eric.Ed.Gov/Fulltext/ED479930.Pdf .(2002).

Sudaryanti. Pentingnya Pendidikan Karakter Bagi Anak Usia Dini. Jurnal Pendidikan Anak, 1(1), 11-20. Https://Doi.Org/10.21831/Jpa.V1i1.2902 (2015).

Sujendra Diputra, K., Ketut Desia Tristiantari, N., Nyoman Laba Jayanta, I., Pendidikan Guru Sekolah Dasar, P., \& Pendidikan Ganesha, U. (2020). Gerakan Literasi Digital Bagi Guru-Guru Sekolah Dasar. JCES (Journal of Character Education Society), 3(1), 118-128. https://doi.org/https://doi.org/10.31764/jces.v3i1.1483

Sosial, B. R. Implemenetasi Pembelajaran Pendidikan Agama Islam Berwawasan Rekonstruk. 6(November) .(2015).

Sugiyono. Metode Penelitian Pendidikan Pendekatan Kuantitatif, Kualitatif, Dan R\&D. Alfabeta. (2016). 
Syarif, i., \& rahmat, r. Penerapan model brain-based learning terhadap peningkatan karakter peserta didik kelas ii sekolah dasar. Edumaspul - jurnal pendidikan, 2(2), 87-90. Https://doi.org/10.33487/edumaspul.v2i2.13 (2018).

Wiyani, N. A. Membumikan Pendidikan Karakter di SD. Ar-Ruzz Media. (2013).

Zulfiati, M., \& Hartiningsih, S. Implementasi Pendidikan Karakter Melalui Budaya Sekolah Di SDN Bandungrejosari 1 Malang. Kebijakan Dan Pengembangan Pendidikan, 6, 1-181. (2018).

Zurqoni, Retnawati, H., Arlinwibowo, J., \& Apino, E. Strategy and implementation of character education in senior high schools and vocational high schools. Journal of Social Studies Education Research, 9(3), 370-397. https://doi.org/10.17499/jsser.01008. (2018) 